\title{
APRENDER A LIBERDADE: REFLEXÕES SOBRE PROJETOS E PRÁTICAS DE ESCOLARIZAÇÃO DE ESCRAVOS, LIBERTOS E INGÊNUOS NO PARANÁ (1871-1888)
}

\author{
Noemi Santos da Silva ${ }^{2}$
}

Resumo: Este trabalho pretende abordar o envolvimento de escravos, libertos e ingênuos com as práticas de instrução formal no final do século XIX, tendo como referência a Província do Paraná. Os aspectos trabalhados neste artigo compõem a fase investigativa inicial de minha pesquisa de Dissertação, na qual trabalho com os projetos e experiências de instrução desse segmento no mesmo período e local. Neste artigo, sintetizo algumas reflexões sobre o tema, levantando, para tanto, breve discussão historiográfica sobre o assunto através do diálogo com a História da Educação. Algumas leis do Império, como as medidas de emancipação e leis de instrução são apresentadas para avaliar como eram norteadas as possibilidades de acesso desses sujeitos ao ensino público. Por fim, algumas evidências de escolarização desse grupo encontradas, sobretudo na documentação escolar paranaense incrementam as análises, indicando a forma como as experiências desses sujeitos com a escola se relacionaram com suas próprias expectativas de liberdade.

\footnotetext{
${ }^{1}$ Esta pesquisa possui financiamento da Coordenação de Aperfeiçoamento de Pessoal de Nível Superior (CAPES)

${ }^{2}$ Mestranda na linha de pesquisa "Espaço e Sociabilidades" do PPGHIS - UFPR sob orientação da Prof. ${ }^{a}$ Dr. ${ }^{a}$ Joseli Maria Nunes Mendonça
} 
Palavras-chave: Abolição - Instrução - Escravos, libertos e ingênuos.

Abstract: This work aims adress the involvement of slaves, freeds and children of slave mothers with practices of formal instruccion in the late of XIX century, in province of Paraná. The aspects worked in this article are part of the initial investigative phase of my Dissertation research in which I work with the projects and experiences of instruccion of this social segment, at the same time and place. In this article, I summarize some reflections about this theme, making quick historiographical discussion about the subject, through a dialogue with the History of Education. Some laws of the Brasilian Empire, as measures of emancipation and laws of education are presented, to assess how they were organized the possibilities of access to public educacion of this subjects. Lastly, some evidences of schooling group, founded in the school documentation of the Paraná increment analyses, showing how this experiences of these subjects with the school were related to their own expectations of freedom.

Keywords: Abolition - Instruccion - slaves, freeds and children of slave mothers. 
Esses milhares de homens validos sem instrução e sem a menor educação não poderão compreender seus deveres de homens livres e nem a obrigação de trabalho. E nessa ilusão do gozo de uma liberdade ilimitada, não ficarão livres da escravidão, a das paixões e dos vícios; GAZETA PARANAENSE, $1884^{3}$.

Estas palavras foram proferidas pelo redator de um dos mais importantes jornais de Curitiba no final do século XIX, pesquisado por Eduardo S. Pena (1999), e refletiam uma inquietação constante circulada nos veículos de imprensa e debates entre autoridades de todo o Império: a insegurança com a Abolição do escravidão e a necessidade de prover meios que garantissem a preparação dos cativos para a liberdade.

Após três séculos de profunda dependência do trabalho escravo, pensar em uma sociedade livre implicava em sérias mudanças de ordem econômica e social que causaram intensas discussões nas diversas esferas políticas imperiais. O processo abolicionista brasileiro teve sua marca gradual por ser nitidamente impulsionado pelas pretensões senhoriais. Os temores por uma Abolição imediata eram balizados por receios da escassez de mão de obra nas grandes lavouras e ainda por

\footnotetext{
${ }^{3}$ GAZETA PARANAENSE, Curitiba, 25 out 1884, 8 (319): 2 e 3. apud. PENA, 1999, p. 103
} 
uma possível desordem social derivada da implantação de libertos na sociedade livre, os quais, supostamente, não compreenderiam o viver em liberdade por serem portadores de vícios que os direcionariam à ociosidade e criminalidade (Mendonça, 2008, p. 48)

Por um lado, parlamentares defendiam a imigração europeia como solução do caos gerado pela Abolição, afinal, o imigrante, desprovido da experiência com o cativeiro não apresentava vícios decorrentes de um passado escravista, tal como o negro liberto. Por outro lado, contudo, a perspectiva da adoção do trabalhador nacional, para muitos políticos, esbarrava nas pretensões "naturais" dos negros às devassidões. Por isso, algumas medidas foram pensadas no sentido de salvaguardar a ordem social e garantir a disciplina dos egressos da escravidão. Controle social era, portanto, um elemento ativo para a manutenção da ordem e garantia do progresso e civilização, aspectos muito caros à elite política nacional do período (Chalhoub, 1986, p. 28).

Para viabilizar as crescentes idealizações de uma sociedade livre, selada pela civilização e progresso, sem os constrangimentos da desordem, a Instrução era afirmada como um dos itens condicionantes da Abolição "prudentemente encaminhada" ${ }^{4}$. Neste processo histórico

\footnotetext{
${ }^{4}$ A expressão foi utilizada pelo parlamentar Mac-Dowell no seu sentido contrário, quando o deputado visava alertar para os perigos de uma abolição "imprudentemente
} 
a ampliação da instrução pública era pensada como um importante agende de correção dos egressos do cativeiro por ter o potencial de direcioná-los para valores morais supostamente ausentes nesta população, guiando-os na sua liberdade para a disciplina do trabalho e ideais de comportamento prezados socialmente. (Fonseca, 2004, p. 05).

É tendo em vista tais fatores que pretendo, neste artigo, discutir a respeito das propostas e práticas de instrução formal, encaminhadas aos escravos, libertos e ingênuos ${ }^{5}$ da província paranaense no final do século XIX. A instrução pública é associada aqui às práticas escolares vigentes no período, tal como apresenta a documentação oficial consultada para a realização da presente pesquisa, em contrapartida, o conceito de educação é aplicado em segundo plano tendo em vista a amplitude de conotações que pode trazer em sua definição. Compreendendo o processo de formação do trabalhador escravo também como prática educativa, utilizamos o termo "educação" com algumas ressalvas, sabendo que o mesmo abrange de tal maneira práticas que transcendem a formação escolar (Fonseca, 2002, p. 125). No entanto, a expressão pôde ser encontrada com frequência nos

encaminhada". Mais detalhes a respeito de suas declarações encontram-se no estudo de Mendonça (2008, pp.46-52).

5 Termo utilizado para denominar os nascidos do ventre de escravas, após a Lei n. ${ }^{\circ} 2040$ de 1871 (Ventre Livre) e que pode ser substituído pela expressão "filho livre de mulher escrava". (Alaniz, 1997, p. 23) 
documentos oficiais como parte integrante dos projetos concernentes à população que seria egressa do cativeiro. Logo, utilizarei "educação" para me referir a estes projetos disciplinadores mais englobantes, mencionados por vezes pelas autoridades do período, e "instrução" ou “educação/instrução formal” para me dirigir às práticas escolares, sobretudo o aprendizado da escrita e da leitura.

O grande debate envolvendo políticas públicas inclusivas para afrodescendentes em todo o contexto nacional repercutiu satisfatoriamente na ampliação de pesquisas que enriquecessem o conhecimento acerca da "história da educação do negro" no Brasil (Gondra \& Schueller, p. 224). A historiografia conta com importantes trabalhos a este respeito, os quais fornecem interessantes vias de análise para compreensão das diversas formas de acesso da população escrava, ingênua e liberta aos bancos escolares de todo o Império, e permitem desenvolver questões ao que se refere à instrução desse grupo na Província do Paraná.

Na província de São Paulo, Surya Barros (2005) apontou para a tendência de estratégias discursivas da elite paulista no sentido de valorizar a educação dos negros de maneira diferenciada e separada. A autora localizou um fragmento de documentação escolar em que é feito um alerta por parte de um professor do ensino público para que 
houvesse medidas públicas para a separação de "negrinhos" que frequentavam as escolas da região. (Barros, 2005, p. 49). No Rio Grande do Sul, Eliane Peres notou, através de um periódico, a profunda preocupação da elite pelotense com a educação dos libertos e ingênuos, os quais eram denominados de "filhos do trabalho" (Peres, 2002, p. 77) e precisavam receber a instrução que os capacitaria a agir moralmente e corrigiria os vícios intrínsecos à raça. No cenário parlamentar, Anarlete Shleubauer analisou diversas falas de políticos do império a respeito da camada social escrava e liberta como foi o caso do político Tavares Bastos, um dos grandes articuladores da emancipação dos escravos, o qual alertava os demais parlamentares em um discurso:

emancipar e instruir é a formula dupla do mesmo pensamento político. O que haveis de offerecer a esses degradados que vão surgir da senzala para a liberdade? O baptismo na instrução. O que reservais para suster as forças productoras esmorecidas pela emancipação? O ensino, esse agente invisível que, centuplicando a energia do braço humano, é sem dúvida a mais poderosa das machinas do trabalho. (Bastos, 1937, p. 240 apud Schleubauer, 1988, p. 49)

As declarações de Tavares Bastos repercutiram significativamente nas publicações de imprensa em diversas regiões do império, de tal forma que a expressão "batismo na instrução" tornou-se 
um dos brasões de discursos emancipacionistas divulgados publicamente (Gondra \& Schueller, 2008, p. 251; Anjos, 2011, p. 107).

Lilia M. Shwarcz (1987) em investigação no jornal A Província de São Paulo detectou a iniciativa de oferta de instrução de escravos e ingênuos interiormente à fazenda de um barão do Oeste Paulista.

\begin{abstract}
Vê-se uns 40 homens de trabalho que tendo largado a enchada e a machada empunham a pena e o livro! Nota-se no semblante de todos o ar risonho cheio de prazer e com todo o silêncio e atenção ouvem as explicações do professor. Terminada as aulas vão fazer suas refeições e descansar até o outro dia. Oxalá que todos os fazendeiros imitassem o exmo. Barão preparando seus míseros escravos para gozarem de sua liberdade quando raiar o dia da redemção. (A Província de São Paulo, apud Schwarcz, 1987 , p. 180, s/d na citação)
\end{abstract}

As palavras do redator do jornal analisado por Schwarcz sustentam os mesmos ideais de educação comentados anteriormente, visíveis na fala do redator do jornal paranaense comentado acima. É manifesto o apelo por iniciativas semelhantes no sentido de fortalecer o preparo dos cativos para a experiência da liberdade. Para compreender a fundo este processo é necessário atrelarmos as medidas emancipacionistas do final do século XIX à ampliação da oferta de instrução em todo o império. As leis promulgadas no período, afinal, acompanharam as tensões expostas na imprensa e nas falas de 
autoridades envolvendo a necessidade da Abolição e os perigos decorrentes de tal medida.

\section{INSTRUÇÃO DE ESCRAVOS, LIBERTOS E INGÊNUOS: DISPOSITIVOS LEGISLATIVOS E PRÁTICAS SOCIAIS.}

Pensar as leis como mecanismos de controle exclusivamente impostos pelos setores dirigentes, reduz a análise historiográfica por não incorporar os embates e os costumes efetuados no plano social, totalmente relevante na construção dos dispositivos legislativos. A produção política das leis tem sido lida por muitos historiadores atualmente como resultado de muitos conflitos de interesse e de classe. A perspectiva levada a cabo por Edward P. Thompson $(1971 ; 1977)$ em suas análises sobre as leis promulgadas no contexto inglês, nesse sentido, é fundamental, por fornecer interessantes vias interpretativas para ponderarmos a importância do costume e conflitos sociais na concepção do direito. Como veremos, os postulados legislativos estiveram em consonância com as práticas sociais envolvendo escravos, libertos e ingênuos no Brasil e no Paraná oitocentista, os quais vinham gradativamente conquistando direitos por meio de ações cotidianas (Chalhoub, 1990, p. 27) 
"Instrução primária gratuita" era um direito de todos os cidadãos brasileiros, como previa a Constituição de 1824 (Art. 179, item 32). Não sendo considerados cidadãos, escravos eram, em decorrência, excluídos de tal benefício público. Assim também decretavam os regulamentos de instrução pública circulados em todo o império. O primeiro deles foi promulgado na Corte em 1854, quando os escravos foram oficialmente proibidos da matrícula e frequência nas aulas públicas ${ }^{6}$.

Em grande medida inspirado nos parâmetros legais da instrução pública na Corte, o Regulamento Geral da Instrução Pública da recémfundada província paranaense, assim como várias outras, três anos depois reproduzia em texto idêntico a proibição da matrícula/frequência de escravos nas escolas:

Art. 39. As matrículas são gratuitas e ficam excluídos delas:

$\S .1^{\circ}$. Os meninos que sofrerem de moléstias contagiosas e mentais.

$\S .2^{\circ}$. Os não vacinados.

$\S .3^{\circ}$. Os escravos.

$\S .4^{\circ}$. Os menores de 5 anos e maiores de 15 .

$\S$. $5^{\circ}$. Os que não houverem sido expulsos competentemente. ${ }^{7}$

\footnotetext{
${ }^{6}$ Decreto ${ }^{\circ} 1331$ de 17 de Fevereiro de 1854.

${ }^{7}$ Regulamento da Instrução Pública. In: (Miguel; Martin, 2004, p. 57)
} 
O Decreto de 1854, contudo, trazia ambiguidades em seu texto, ao deixar vaga às condições para matrícula de adultos no ensino público. Era previsto que os professores de escolas secundaristas se dedicassem à instrução básica de adultos em horários que lhes fossem pertinentes, não constando nenhuma restrição para matrícula de seu alunado nesta modalidade de aprendizado $^{8}$. Como veremos, esta postulação dúbia abriu espaço para iniciativas de escolarização para escravos no período noturno, mesmo sendo enfática a exclusão dos mesmos nas aulas públicas.

A década de 1870 marcou a culminação da iminência da Abolição da escravidão no contexto nacional. Considerada por muitos estudiosos o grande símbolo da Abolição gradual brasileira (Ramos, 2008; Pena, 2001; Alaniz, 1997), a Lei n²040 de 28 de Setembro de 1871, mais conhecida como Lei do Ventre Livre, selava a proximidade da emancipação geral dos cativos libertando as próximas gerações que nasceriam em cativeiro. Essa lei possui importância ímpar em todo debate relacionado ao fim do escravismo brasileiro, pois, estabelecia uma estratégia peculiar para o enfretamento desse processo de transição, assinalando para a evidente crise pela qual passava o regime escravista, tendendo a dosar a liberdade que seria dada aos cativos e

\footnotetext{
${ }^{8}$ Decreto ${ }^{\circ} 1331$ de 17 de Fevereiro de 1854, Art. 71
} 
protelando a abolição. A preocupação em se adiar ao máximo a eliminação da instituição escravista era justificada por se temer que os cativos ocasionassem prejuízos à ordem e à economia nacional.

Os filhos de mulheres escravas, nascidos após a referida Lei foram chamados de ingênuos, termo que deriva do Direito Romano, o qual designa quaisquer indivíduos nascidos livres, independente de uma procedência escrava, liberta ou livre (CRETELLA JR, apud ALANIZ, 1997, p. 23). Este termo foi empregado em decretos posteriores como sinônimo da expressão "filhos livres de mulher escrava", maneira como a Lei do Ventre Livre fazia referência a tais indivíduos.

Quando se tem em vista que a lei de 1871 foi formulada no sentido de se prolongar qualquer medida drástica de erradicação da instituição escravista, reforça-se a ideia de que os grupos dirigentes preocupavam-se amplamente com o futuro daqueles que se tornavam livres, mesmo que gradualmente. Logo, era firmada também a visão de que tanto cativos quanto libertos deveriam aprender a viver em condição de liberdade. É dessa maneira que surgem propostas de enquadramento desses indivíduos na sociedade livre por meio da instrução e da disciplina ao trabalho. A Lei do Ventre Livre reuniu ambas as expectativas quando definiu que a liberdade da criança ingênua deveria ser aproveitada sob os olhos e vigilância do senhor da 
mãe escrava, o qual inclusive teria o direito de explorar o trabalho do menor.

Inicialmente a medida estabelecia que o ingênuo devesse permanecer em posse do senhor da mãe até a idade de 8 anos, chegado a esta faixa etária, o então senhor optaria entre entregar a criança ao Estado, recebendo uma indenização de 600 mil réis, ou então permanecer com o menor aproveitando os serviços do mesmo, até que este completasse a idade de 21 anos. No caso da entrega do ingênuo ao Estado, o governo encaminharia o menor às associações por êle autorizadas às quais teriam por função se responsabilizar pela criança (Art. 2). Porém, se o senhor optasse pela guarda dos menores, teria por obrigação "criá-los e tratá-los" até que completassem a maioridade. A irrisória indenização oferecida pela entrega do ingênuo ao governo, sem dúvida, desestimulou os senhores para esta ação resultando num ínfimo número de crianças entregues à responsabilidade estatal, apenas $0,1 \%$ em 1885, como constatou Alaniz (1997, p.41). Logo, o Estado brasileiro do período demonstrava sua preocupação com o "amparo" de ingênuos, de maneira peculiar, jogando essa responsabilidade aos senhores das mães, admitindo a falta de estrutura pública em se responsabilizar por tais crianças. 
O forte teor ambíguo das postulações da lei não explicita quais medidas seriam tomadas com relação à instrução primária dos ingênuos. Contudo, tanto no caso de serem entregues ao Estado, quanto na opção de permanecerem sob "posse" do senhor de suas mães era evidente o usufruto gratuito do trabalho do menor por parte do responsável. Isso evidencia o quanto a lei significou no tocante ao controle da mão de obra ao propor um pacto desigual em que o proprietário recebia incontáveis benefícios lucrativos sobre o ingênuo, recriando o mesmo modelo de dependência da escravidão e estabelecendo a liberdade restrita à qual estavam sujeitos os supostamente "beneficiados" pelas medidas abolicionistas.

Os anseios despertados pela crescente demanda de ingênuos na sociedade estimularam debates entre os grandes proprietários das diversas regiões brasileiras, reunidos nos Congressos Agrícolas de 1878, para definir qual futuro tomariam os filhos livres de mulher escrava, e de que maneira os latifundiários de todo o império amenizariam seus prejuízos com a gradual libertação dos escravos. Tais reuniões, realizadas no Rio de Janeiro e em Recife, sintetizam os modelos educacionais forjados para os ingênuos daquele período, consolidando um ideal de liberdade restrita para estes indivíduos. 
Em estudo sobre tais congressos de 1878, Fonseca (2004) menciona a maneira como se articularam as soluções sugeridas pelos latifundiários para a devida supressão da crise pela qual passava o setor agrícola brasileiro do período em tempos de abolição. Em consenso, congressistas do Recife e do Rio de Janeiro defenderam uma educação específica para aqueles nascidos do ventre de suas escravas após a Lei de 1871. Para os ingênuos deveria ser ofertada uma educação voltada para o trabalho, a qual os preparasse a servir devidamente, de maneira disciplinada com a devida instrução moral, e, sobretudo, separadamente das demais crianças livres. Estes espaços "separados" priorizavam "a formação das crianças como trabalhadores agrícolas, longe de qualquer perspectiva de formação de cidadãos como era frequente nos discursos sobre o papel da educação durante o Império." (Fonseca, 2004, p. 06).

Na província do Paraná, enquanto isso, a real condição dos ingênuos não era assimilada por parte de alguns sujeitos do ensino público. Assim como em todo o império foi comum o envio de cartas dirigidas às autoridades competentes, indagando a pertinência da matrícula de filhos livres de mulher escrava nas escolas públicas (Gondra \& Schueller, 2008, p. 250). Em 1879, José Agostinho, professor da Cadeira de Palmeira redigia uma correspondência à 
autoridade da instrução pública questionando se devia ou não admitir um ingênuo em sua escola:

Tendo sido apresentado a matricula na escola a meu cargo um menino filho de mulher escrava, liberto pela Lei $\mathrm{n}^{\circ} 2040$ de 28 de Setembro de 1871, rogo a V.Exc. ${ }^{a}$ que se digne a dizer se devo admitillo em cargo do que diz o Art.39§2 do Regulamento da Instrução Pública. ${ }^{9}$

O trecho de legislação citado pelo professor trata-se da restrição à matrícula de escravos nas aulas públicas ${ }^{10}$, logo, Agostinho considerou o menor, antes como liberto, depois como escravo. Se nascido livre, o ingênuo não era considerado liberto, tampouco escravo. Isso denota o quanto a real condição desses menores causou imprecisão entre aqueles que de alguma forma se envolveram com tais indivíduos.

Foi, sem dúvida, em decorrência de tais situações que as autoridades da instrução pública finalmente adotaram uma postura legislativa perante a inclusão de ingênuos no ensino público da província paranaense. Em 1883 após mais de uma década de aprovação da Lei $n^{\circ}$ 2040, o regulamento de instrução pública da província do Paraná incluiu ingênuos no rol de crianças atingidas pela

\footnotetext{
${ }^{9}$ Correspondência de governo. Arquivo Público do Paraná; Livro: BR APPR n. ${ }^{\circ}$ 564, p. 12.

${ }^{10}$ Regulamento da Instrução Pública. In: (Miguel; Martin, 2004, p. 57).
} 
obrigatoriedade escolar $^{11}$. Desde 1879, entretanto, os menores já haviam atingido a idade escolar e, como crianças livres, não se encontravam juridicamente impedidos de frequentarem escolas públicas, pelo contrário, já compunham o conjunto de menores atingidos pela obrigatoriedade.

Esta medida, entretanto, não surtiu grandes efeitos haja vista as muitas manifestações contrárias de professores locais à respeito da grande quantidade de ingênuos longe das aulas ou então frequentando escolas noturnas da região, destinadas exclusivamente aos adultos. Um deles foi o polêmico professor Pedro Saturnino da Cadeira de Castro, reclamante assíduo nas correspondências de governo de cunho escolar da província, sempre cobrando das autoridades maior atenção aos assuntos do cotidiano escolar. O professor, em carta ao Inspetor Geral da Instrução Pública alertava para o "crescido número de ingênuos $e$ libertos nas condições de frequentarem a eschola pública de menores, $e$ que por desleixo dos pais e tutores acham-se jazendo nas trevas" 12. Alguns anos depois, em correspondência de mesmo teor o professor contestava a permanência de menores ingênuos nas aulas noturnas mesmo após uma condenação partida diretamente do imperador D.

\footnotetext{
${ }^{12}$ Correspondência de governo. Arquivo Público do Paraná, Livro BR APPR n 662, p. 241.
} 
Pedro II em visita à província do Paraná que condenou a frequência de menores no ensino noturno, ao menos que as crianças comprovassem exercerem algum ofício durante o dia ${ }^{13}$.

De fato, o grande número de ingênuos frequentando o ensino noturno atrela-se à proximidade com a qual tais menores viveram do cativeiro, sendo criados pelos senhores de suas mães, exercendo gratuitamente seus serviços. Entretanto, reflete ainda o ideal de instrução pensado por grandes proprietários e autoridades para estas crianças: espaços escolares separados, próprios para a formação de trabalhadores (Fonseca, op.cit). Quando temos em vista que grande parcela das escolas noturnas do Paraná foi frequentada consideravelmente por escravos e libertos, como veremos adiante, nos aproximamos do quanto à experiência de tais crianças esteve associada ao trabalho e ao cativeiro. Como reforça Eliane Peres (2002), o que ligava esses menores as aulas noturnas era $o$ fato de serem trabalhadores, afirma a autora tendo como referência a presença de ingênuos em um curso noturno da região de Pelotas:

Era sobretudo na condição de trabalhadoras que crianças do sexo masculino podiam freqüentar as aulas, visto que o trabalho infanto-juvenil era uma realidade [...].Era como

${ }^{13}$ Correspondência de governo. Arquivo Público do Paraná, Livro BR APPR n 603 , p. 209 
trabalhadores, e não como crianças, que estes sujeitos tinham acesso aos cursos. Ser trabalhador, porém, era antes uma justificativa que uma exigência (Peres, 2002, p. 88)

Não interpretamos como coincidência ainda, o fato de medidas de apoio à ampliação do ensino noturno na Província serem despertadas na década de 1870, período de desenvolvimento das políticas abolicionistas, portanto de "transição" do trabalho escravo para o trabalho livre. No Paraná, a lei de estímulo à criação de escolas noturnas para adultos entrou em vigor em abril de $1872^{14}$. A escolarização no período noturno, criada especialmente para adultos era visada, entre outros motivos, para proporcionar o aprendizado básico de ofícios, essenciais para garantir mão de obra especializada nas regiões onde a urbanização e industrialização já eram evidentes (Peres, 2002). No Paraná, devemos ressaltar o impacto causado pela economia do mate nas condições do mercado e das cidades da província. A indústria do mate, segundo Magnus Pereira (1996) foi decisiva no processo de urbanização e modificação das relações de trabalho desde meados do século XIX, portanto, estimulou a desarticulação do trabalho escravo (Pereira, 1996, p. 12).

\footnotetext{
${ }^{14}$ Lei n. ${ }^{\circ} 330$ de 12 de Abril de 1872. In: MIGUEL, M.E.B.; MARTIN, S. D., 2004, p. 209.
} 
A difusão do ensino noturno, no caso paranaense, foi crucial para proporcionar inserção de escravos, libertos e ingênuos nas escolas públicas, muito embora a restrição dos primeiros estivesse explícita na legislação. Curioso, contudo é perceber que a presença conjunta deste grupo compunha um número grandioso do alunado desta modalidade de ensino. Atentar para o contexto de formação de tais escolas, bem como para alguns sujeitos envolvidos neste processo pode auxiliar na compreensão de algumas experiências de escravidão e liberdade delineadas a partir de "brechas" na legislação.

\section{ESCRAVIDÃO, LIBERDADE E ESCOLARIZAÇÃO: UMA ANÁLISE A PARTIR DAS ESCOLAS NOTURNAS DO FINAL DO SÉCULO XIX.}

Paranaguá, 1871. O Professor José Cleto Silva, mais conhecido como "professor Cleto" escrevia ao Inspetor Geral da Instrução Pública da Província pedindo permissão para abrir uma escola noturna destinada a escravos no mesmo local onde lecionava no período diurno.

Desejando eu, servindo-me do que disponho com uma tão fraca inteligência, suprido apenas pela boa vontade. Fazer com que seja a instrucção primária pela partilha de todos nesta cidade, e contando nesse empenho com o valioso 
auxílio de V.S a como digno chefe de um dos mais importantes ramos do serviço público, tenho a distinta honra de pedir a V. Sa que se digne de conceder-me licença para abrir eu uma escola noturna, na mesma casa em que funciona a diurna sob minha direção, na qual possão receber os rudimentos da instrucção aquelles de nossos irmãos que infelizmente trazem na fronte 0 avillante selo da escravidão e cujos senhores nisso consentirão. ${ }^{15}$

Cleto dizia considerar os escravos como “irmãos”, entretanto, evidentemente era ciente da proibição da matrícula dos mesmos no ensino público, daí a iniciativa em pedir a permissão para a abertura da escola. Não sabemos em qual medida o Decreto de 1854 influenciou na execução de sua iniciativa, todavia, podemos situar sua ação nas brechas legislativas concernentes à escolarização dos escravos existentes até então. O professor chama atenção para seu caráter filantrópico para justificar seu empreendimento - algo dentro dos limites da normalidade para um homem que pretendia seguir carreira política, porém, evidencia que sua ação não foi motivada pelos senhores da região, mas sim, que estes apenas "consentiriam" na iniciativa que estava prestes a realizar.

Não foi possível identificar a resposta do inspetor geral à petição de Cleto, tampouco houve anexo da lista dos alunos que provavelmente

${ }^{15}$ Correspondência de governo. Arquivo Público do Paraná; Livro: BR APPR n. ${ }^{\circ}$ 385, p. 123. 
se matriculariam. Porém, houve menções à "escola noturna do professor Cleto" na documentação educacional de maneira geral nos anos seguintes, o que evidencia que a escola funcionou, tal como pretendia seu idealizador.

Investigando a documentação escolar do período, pudemos chegar à conclusão de que o professor Cleto se encontrava "à par" dos debates políticos realizados no presente contexto, especialmente aqueles destinados a discutir o fim do escravismo brasileiro, afinal, sua trajetória denota um grandioso empenho em se tornar homem público, pretensão realizada na década de 1880 , quando Cleto tomou assento na Assembleia Provincial. Tamanho fora seu destaque, que seu nome foi dado à sua escola em Paranaguá, a uma rua e uma praça da mesma cidade onde atualmente se encontra erguida uma placa de bronze, onde é possível verificar a abrangência de seu ativismo, bem como uma série de comentários elogiosos a respeito de sua carreira no magistério e na vida pública. Merece destaque, portanto, a relação possível entre o engajamento político de José Cleto e sua atitude em abrir uma escola pra cativos, mesmo quando, legalmente, não era permitido que escravos frequentassem as aulas públicas. Cleto, como nos indica a documentação, foi um homem com muitos anseios de exercer profissão pública, e, por isso, "investiu" na instrução de grupos populares - 
inclusive escravos - acreditando que isso seria um importante elemento para o progresso.

Em 1880, provavelmente antes de Cleto assumir o assento na Assembleia Provincial, o inspetor paroquial fez uma visita na escola noturna deste professor, registrando suas impressões em um "termo de visita". Nos seus escritos, o inspetor falava de uma grande quantidade de alunos, além de destacar a disciplina e bons tratos dos mesmos: "Achavam-se presentes oitenta e cinco alumnos que trajavam decentemente. A sala que funciona a aula é vasta e em boas condições de hygiene" ${ }^{\prime 16}$.

Surpreende o crescido número de alunos presentes na aula noturna de Cleto, a qual, ao menos de início, era visada para contemplação da instrução de escravos, exclusivamente. Novamente é necessário enfatizar que no contexto no qual Cleto efetivara sua iniciativa, surgiam no âmbito legal, evidências concretas da emancipação gradual dos escravos, cujo exemplo mais notável é a Lei de 1871, portanto, suas ações não podem ser vistas como isoladas de uma conjuntura propícia para a efetivação de medidas voltadas à instrução de cativos e egressos da escravidão.

\footnotetext{
${ }^{16}$ Correspondência de governo. Arquivo Público do Paraná; Livro: BR APPR n. ${ }^{\circ}$ 599; p.126.
} 
Tomando isto por princípio, seguimos a diante na investigação de demais iniciativas semelhantes à do professor Cleto e nos deparamos com inúmeros casos de escolas noturnas compostas por escravos, libertos e ingênuos no Paraná, algumas inclusive frequentadas majoritariamente por este grupo.

Conforme mencionado acima, 1872 foi o ano de promulgação da lei de incentivo à criação de escolas noturnas para adultos. Não demoraram surgir, em decorrência, as aulas noturnas previstas pela medida legal. Na capital, inaugurou-se uma delas, com muitas características semelhantes à escola noturna de Cleto. A escola tinha a regência de Damasco Correia Bittencourt, que abriu o estabelecimento no ano de 1874. Não pudemos encontrar muitos detalhes sobre a vida e a escola de Bittencourt, entretanto, localizamos o mapa dos alunos de sua escola, o qual possibilitou traçar um perfil geral daqueles que frequentaram estabelecimentos voltados ao ensino de adultos trabalhadores. Ao contrário de Cleto, esse professor não pediu permissão à autoridade competente para abrir uma escola para escravos, apenas comunicou, enviando inclusive dados relacionados ao espaço que abriu, enfatizando promover a instrução "da classe menos protegida pela fortuna [...] que com consentimento de seus senhores 
desejam aprender a ler, escrever e contar" ${ }^{17}$. Na correspondência, Bittencourt mencionava destinar o ensino para "escravos e operários", os quais já somavam, no ano de abertura, a quantia de 23 alunos. Estes se dividiam entre os mais variados ofícios: pedreiros, carpinteiros, sapateiros e alfaiates, não havendo entre eles nenhum padrão de faixa etária, pois na mesma aula noturna de Bittencourt frequentavam alunos dos 10 aos 60 anos de idade ${ }^{18}$.

Interessante é atentar para dois principais aspectos da correspondência e lista de alunos da escola de Bittencourt. O professor, em carta, afirma direcionar o letramento aos "escravos e operários", contudo, conforme indica sua lista de matriculados, seu alunado é composto exclusivamente de escravos e libertos. Estes, portanto, foram denominados de "operários". Isto merece destaque na medida em que indica que o professor instruía seletamente indivíduos que possuíam vínculo com o cativeiro e os denomina com uma terminologia empregada para atrelar a condição de liberto a uma ocupação de trabalho. Neste ponto é imprescindível levarmos em consideração as constantes inquietações, manifestas pelas autoridades no período, por uma ameaçadora onda de ociosidade, supostamente ocasionada pela

\footnotetext{
${ }^{17}$ Correspondência de governo. Arquivo Público do Paraná; Livro: BR APPR n. ${ }^{\circ} 447$, pp.93-94

idem
} 
emancipação dos escravos (Chalhoub, 1986). A escola noturna, vista como ambiente de correção de vícios, está implicitamente associada na correspondência como um espaço destinado a trabalhadores, portanto, em consonância com o combate à ociosidade tão propagado em todo o império.

O segundo aspecto para o qual é crucial atentar é a afirmação de Bittencourt de direcionar o ensino a "escravos que desejam aprender a ler, escrever...". Mais uma vez, assim como no caso de José Cleto, este não foi um empreendimento encabeçado por senhores de escravos, mas sim mobilizado pelos cativos, possivelmente agindo em busca de melhores condições na concorrência do trabalho. Isso corrobora na perspectiva de desconstrução da teoria historiográfica denominada por Sidney Chalhoub (1990) de "escravo-coisa" em que os escravos são concebidos unicamente como vítimas, dados estatísticos ou força de mão de obra. Aqui há perfeita demonstração do quanto os mesmos tinham plena consciência do conjunto de ações propícias para ascenderem socialmente e promoviam ações que contribuíssem para o alcance de melhores condições de vida.

Em 1882, o então presidente da província Jesuíno Marcondes de Oliveira e Sá fez um levantamento estatístico das escolas noturnas do Paraná do período. Nos dados que apresentou, ele frisou a importância 
da criação de escolas noturnas na província, para o necessário letramento das camadas mais pobres da sociedade, os "menos favorecidos", que naquele momento poderiam participar da cidadania como eleitores, além de se alistarem para o setor militar, desde que fossem alfabetizados. O mesmo presidente informou a existência de 361 alunos registrados nesse setor de instrução, sendo 71 deles escravos, ou seja, aproximadamente $20 \%$ dos matriculados ${ }^{19}$.

A década de 1880 é, sem dúvida, o período no qual a presença de escravos, libertos e ingênuos nas escolas noturnas é ainda mais evidente na documentação escolar da província paranaense. No mesmo relatório anual de Jesuíno Marcondes de Oliveira e Sá, o presidente da província faz referência a um espaço escolar, também noturno, desta vez com características ainda mais peculiares: foi "aberto e mantido por escravos" sendo dirigido pelo typografo João Teodoro Silva ${ }^{20}$, situado na cidade de Paranaguá. No mesmo ano, nas redondezas da região litorânea da província, desta vez, na Vila de Morretes, um colégio particular é cursado majoritariamente por escravos que "com permissão

\footnotetext{
19 Jesuino Marcondes de Oliveira e SÁ. Relatório do Presidente da Província do Paraná, ano: 1882, p. 93.

${ }^{20}$ Idem.
} 
de seus Senhores" a frequentavam, "com mais ou menos regularidade, havendo entre eles a maior boa vontade de aprender" 21.

Dezenas de mapas escolares ${ }^{22}$, dispersos na documentação escolar da província sustentam a ampla frequência de escravos, libertos e ingênuos no ensino escolar noturno da província, sobretudo a partir da década de 1870. Por razões de espaço, não comentaremos aqui cada caso, contudo, devemos sublinhar algumas características que se sobressaem em todos os documentos: a frequência conjunta entre escravos, libertos, ingênuos e livres e a ampla presença de menores nas aulas, especialmente ingênuos. Diferentemente dos casos comentados inicialmente, nos quais as escolas foram destinadas exclusivamente aos escravos, nas escolas noturnas identificadas através de mapas escolares percebemos que embora houvesse uma disposição legal que proibisse a convivência entre livres e escravos nas escolas, essa convivência ocorreu e de maneira muito significativa. Logo, os escravos não estudavam separadamente dos livres, em espaços exclusivos para a sua condição, estavam incluídos nas políticas voltadas para a expansão da educação das camadas sociais populares para a qual era visada a

\footnotetext{
${ }^{21}$ Assim afirmava o inspetor paroquial num "Relatório de Visita" AP 659; p. 122

${ }^{22}$ Modalidade da documentação escolar onde são mencionados alguns detalhes sobre os alunos matriculados, tais como idade, profissão, condição e, em alguns casos, rendimento.
} 
educação para o trabalho no sentido de promover a preparação da mão de obra qualificada para o trabalho livre (Peres, 2002).

No tocante à escolarização dos ingênuos, entretanto, a tendência de "separação" dos mesmos foi evidente na medida em que, em geral, não foram escolarizados juntamente com as demais crianças livres, havendo para eles o mesmo projeto de instrução para o trabalho visado para a população escrava e liberta. Como indica Cláudia Ramos, isso pode evidenciar a articulação das políticas de instrução ao problema de mão de obra enfrentado no império com a iminência do processo abolicionista.

Foi em relação a questão do resgate da geração das crianças negras que nasceriam livres de mães escravas, que surgiu a preocupação em garantir a organização do mundo do trabalho, sem o recurso e as políticas de domínio características do cativeiro. (Ramos, 2008, p. 74)

Estas experiências nos direciona a concluir uma efetiva concretização dos projetos de ampliação da instrução pública para as classes marginalizadas, além de demonstrar indícios da profunda preocupação com a educação cívica dos egressos da escravidão, a qual se desenvolveu de maneira dúbia por criar um modelo específico de escolarização para estes indivíduos, separando-os do ideal de educação ofertada para o restante da sociedade. 


\section{ESCOLAS E EXPERIÊNCIAS DE LIBERDADE - CONSIDERAÇÕES FINAIS.}

Para encerrar, gostaria de apresentar um último e formidável caso que pode elucidar muitas questões exploradas até então. Trata-se der um processo judicial movido por Francisca Romana da Cunha em 1887. Ela liberta desde 1882, lutava para não ser reescravizada por seu antigo senhor utilizando como ferramenta comprobatória de sua liberdade a matrícula e frequência em uma escola pública de Paranaguá, onde residia.

Apesar de ser ela de condição livre, comprova com a carta de liberdade, junta em original, competentemente reconhecida e registrada, escripta e assignada pelo próprio punho de seu ex-senhor a 2 de Maio de 1882, comprova-o ainda com o facto de tê-la inscipta néssa qualidade conforme a ezigência do art. $\mathrm{n}^{\circ} 39 \S 2^{\circ}$ do Regulamento da Instrução Pública da Província de 16 de Junho de 1876, na $2^{\text {a }}$ Cadeira da referida cidade de Paranaguá, regida pela professora pública Dona Maria Julia da Silva Nascimento. $^{23}$

O trecho de Regulamento da Instrução citado no processo é o mesmo mencionado pelo professor José Agostinho da Cadeira de

${ }^{23}$ DEAP-PR - PB045. PI8334.321. 
Palmeira, o qual buscava sanar suas dúvidas a respeito da aceitação de um ingênuo em sua escola. Trata-se da tão afirmada restrição de escravos nas aulas públicas.

Ora, todos os indícios levantados pelas fontes até então nos instiga a questionar a validade dos dispositivos legislativos destinados a restringir o acesso de escravos às aulas. Entretanto, a partir do caso de Francisca Romana temos uma visão alternativa do significado da instrução em tempos de escravidão: ao encaminhar sua matrícula como símbolo da legitimidade de sua liberdade, percebemos o quanto o ambiente escolar foi visado como espaço de experiência de liberdade por muitos cativos, libertos e até ingênuos. Isso, no momento de transição, pelo qual passava a nação brasileira - do trabalho escravo para as relações de trabalho livre - revela o quanto estes indivíduos vivenciaram condições de "fronteira" (Alaniz, 1997, p. 39) entre a escravidão e a liberdade e buscavam na escolarização um meio de afirmação de liberdade ou, quem sabe uma garantia da mesma. Nas palavras de Fonseca:

a população negra, que sempre podia ser confundida com os escravos, que a escola acenaria como um passaporte para a afirmação da condição de livre e indicaria a oportunidade de usufruir da liberdade. Nesta perspectiva, a escola seria uma forma de demonstração de domínio dos códigos de liberdade, cuja principal característica seria 
demarcar um distanciamento da escravidão. (Fonseca, 2007, p.207)

O modelo de instrução experimentado por escravos, libertos e ingênuos no final do século XIX paranaense nos leva a problematizar a inserção de cativos e emancipados na sociedade livre. Esta inclusão trazia consigo todas as contradições inerentes aos projetos de abolição, as quais foram ainda explicitadas na legislação vigente.

O escravo, por não ser cidadão, estava excluído do acesso ao ensino público pela via legal, no entanto, estava autorizado a frequentar espaços de instrução no período noturno, medida pública de escolarização fortemente intensificada a partir dos anos finais do regime escravista no Império. Esta modalidade de escolarização era favorecida na medida em que teria o potencial de proporcionar benefícios ao grupo social "degradado" pelo cativeiro, e assim, promover o progresso e civilização tão almejados pelas elites.

A maneira como se promoveu a instrução deste setor social, portanto, revela o favorecimento de um modelo específico de educação voltada tais indivíduos, o qual pode revelar a tendência em considerálos a partir da "marca da escravidão", como sugeriu Pena (1999, p. 94). Logo, mesmo os ingênuos, constituídos como nascidos livres vivenciaram cotidianos atrelados à escravidão, como bem definiu Kátia 
Mattoso, "Numa época em que começaram a prolongar-se a infância e os folguedos, o filho da escrava continua tendo uma infância encolhida, de tempo estritamente mínimo." (Mattoso, 1988, p. 55). Situando-se, em sua maioria, juntamente a escravos e libertos nas escolas noturnas e no cativeiro - sob "proteção" do senhor de sua mãe, os ingênuos distanciaram-se da condição das demais crianças nascidas livres nos estabelecimentos escolares diurnos, desfrutando de uma experiência de liberdade significativamente limitada. 


\section{REFERÊNCIAS BIBLIOGRÁFICAS}

\section{Fontes}

- AP's, correspondências de governo encontradas no acervo do Arquivo Público do Paraná. Livros: BR APPR n. : 339, pp. 250-255; AP 389, p. 130; AP 385, p. 123; AP n. ${ }^{\circ} 435$, p.188; AP n. ${ }^{\circ} 458$, pp. 135-13; AP n. ${ }^{\circ}$ 476, p. 101; AP n. ${ }^{\circ} 447$, p. 94; AP n. ${ }^{\circ}$ 564, p. 12; AP n. ${ }^{\circ} 666$, p. 266; AP n. ${ }^{\circ}$ 603, p. 209; AP n. ${ }^{\circ}$ 637, p. 209

- Relatórios de Presidente de Província (1854-1889).

- Legislação Educacional da Província do Paraná, in: MIGUEL, M.E.B. e MARTIN, S.D.(org.). Coletânea da Documentação Educacional Paranaense no período de 1854 a 1889. in:.Coleção Documentos da Educação Brasileira [recurso eletrônico] - Dados Eletrônicos Brasília: Instituto Nacional de Estudos e Pesquisas Educacionais Anísio Teixeira, 2004

- Arquivo Público do Paraná; Catálogo seletivo de documentos referentes aos africanos e afrodescendentes livres e escravos. Curitiba: Imprensa Oficial, 2005

- Legislações: Constituição Imperial de 1824: "Constituição Política do Império do Brazil." Disponível em: http://www.planalto.gov.br/ccivil_03/constituicao/constituiçao24.htm Lei número 2040 de 28.09.1871. Disponível em: 
Revista Vernáculo, $n^{\circ} 28,2^{\circ} \mathrm{sem} / 2011$

http://www.planalto.gov.br/ccivil_03/LEIS/LIM/LIM2040-1871.htm

\section{BIBLIOGRAFIA}

ALANIZ, Anna Gicelle García. Ingênuos e Libertos: estratégias de sobrevivência familiar em épocas de transição. 1871-1895. Campinas: Área de Publicações CMU/UNICAMP, 1997.

ANJOS, Juarez José Tuchinski. Uma trama na História: a criança no processo de escolarização nas últimas décadas do período Imperial (Lapa, Província do Paraná 1866-1886). Dissertação apresentada ao PPGE/UFPR, Curitiba, 2011.

CHALlOUB, Sidney. Trabalho, Lar e Botequim. São Paulo: Brasiliense, 1986.

- Visões da Liberdade: uma história das últimas décadas da escravidão da corte. São Paulo: Companhia das Letras, 1990.

FONSECA, Marcus Vinícius. "Educação e Escravidão: um desafio para a análise historiográfica". In: Revista Brasileira de História da Educação. Edição de Julho/ Dezembro, 2002.

- Escolas para crianças negras: uma análise a partir do Congresso Agrícola do Rio de Janeiro e do Congresso Agrícola do Recife, em 1878. Anais do III Congresso de História da Educação, 2004. 
Revista Vernáculo, $n^{\circ} 28,2^{\circ} \mathrm{sem} / 2011$

. Pretos, pardos, crioulos e cabras nas escolas mineiras do século XIX. Tese em Educação. Universidade de São Paulo: 2007.

GONDRA, José Gonçalves \& SCHUELLER, Alessandra. Educação, poder e sociedade no império brasileiro. Biblioteca Básica de História da Educação, v. 1, São: Paulo: Cortez, 2008.

MATTOSO, Kátia de Queirós. "O Filho da Escrava (Em torno da Lei do Ventre Livre)". In: Revista Brasileira de História v.8, ${ }^{\circ} 16$. São Paulo, 1988.

MENDONÇA, Joseli M. N. Entre a mão e os anéis: a Lei dos Sexagenários e os caminhos da abolição no Brasil. $2^{\mathrm{a}}$ edição. Campinas: Ed. Unicamp, 2008.

PENA, Eduardo S. O jogo da face: a astúcia escrava frente aos senhores e a lei na Curitiba provincial. Curitiba: Aos Quatro Ventos, 1999.

PERES, Eliane. "Sob(re) o silêncio das fontes: a trajetória de uma pesquisa em história da educação e o tratamento das questões étnicoraciais". In: Revista Brasileira de História da Educação. Edição de Julho/ Dezembro, 2002.

RAMOS, Claudia Monteiro da Rocha. A escravidão, a educação da criança negra e a Lei do Ventre Livre (1871) e pedagogia da 
Revista Vernáculo, $n^{\circ} 28,2^{\circ}$ sem/2011

escravidão. Dissertação de Mestrado defendida na UNICAMP. Campinas, SP: s.n, 2008.

SHLEUBAUER, Anarlete R. Idéias que não se realizam. O debate sobre a educação do povo no Brasil de 1870 a 1914. Maringá: EDUEM, 1988

SHWARCZ, Lilia Moritz. Retrato em branco e negro: jornais, escravos e cidadãos em São Paulo no fim do século XIX - Companhia das Letras, 1987.

THOMPSON, E. P, Senhores e Caçadores. A Origem da Lei Negra. Rio de Janeiro: Paz e Terra, 1987. 